\title{
ERRATUM TO: PUTTING CONTEXT IN CONTEXT: AN EXAMINATION OF THE EVIDENCE FOR THE BENEFITS OF 'CONTEXTUALISED' TASKS
}

\section{Erratum to: Int J Sci Math Educ (2011) 9:367-390 DOI:10.1007/s10763-010-9270-z}

This article unfortunately contains a mistake. The quote on page 377 of this article from a text by Van den Heuvel-Panhuizen (1999) is incorrect.

On this page, Kim Beswick wrote:

Consistent with Freudenthal's (1968) view, Van den Heuvel-Panhuizen (1999) explained that problem solving in RME is focussed on helping students to mathematise and with the aim of developing mathematical concepts. Suitable problems "should be unambiguous; should provide students with all the data needed; should only have one correct answer, and so on." (p. 142)

Later in the paper, on page 383, Beswick again explained that in Realistic Mathematics Education

[...] context problems should be unambiguous, provide all needed data, have one correct answer (at least when used for assessment) [...].

This is completely the opposite of what Van den Heuvel-Panhuizen has argued for in several publications (e.g. Van den Heuvel-Panhuizen \& Becker, 2003) and says in her text on page 142 in Van den HeuvelPanhuizen (1999):

Psychometric-based testing can never be a complete model for didactical assessment. Developing didactical assessment problems implies ignoring a number of traditional requirements for assessment problems and dispelling a number of misconceptions about mathematical problems which have long determined assessment, namely that assessment problems:

- should be unambiguous;

- should provide students with all the data needed;

- should only have one correct answer, and so on.

The online version of the original article can be found at doi:10.1007/s10763-010-9270-z.

International Journal of Science and Mathematics Education (2011) 9: 1485-1486

(c) National Science Council, Taiwan 2011 


\section{REFERENCES}

Van den Heuvel-Panhuizen, M. (1999). Context problems and assessment: Ideas from the Netherlands. In I. Thompson (Ed.), Issues in teaching numeracy in primary schools (pp. 130-142). Maidenhead, UK: Open University Press.

Van den Heuvel-Panhuizen, M. \& Becker, J. (2003). Towards a didactic model for assessment design in mathematics education. In A. Bishop, M. Clements, C. Keitel, J. Kilpatrick \& F. Leung (Eds.), Second international handbook of mathematics education (pp. 689-716). Dordrecht, the Netherlands: Kluwer Academic.

Faculty of Education

University of Tasmania

Locked Bag 1307, Launceston, Tasmania 7250, Australia

E-mail:Kim.Beswick@utas.edu.au 